\title{
PERANCANGAN SISTEM INFORMASI REKONDISI ALAT BERAT PADA PT JAYA KONSTRUKSI MANGGALA PRATAMA
}

\author{
Zyad Rusdi $^{1}$, Ria Ekawati ${ }^{2}$, Dwi Ratna Ningtiyas ${ }^{3}$ \\ ${ }^{1}$ Sistem Informasi, Universitas Tarumanagara J1. Letjen S. Parman, Jakarta 11440 Indonesia \\ ${ }^{2}$ Karyawan Adminitrasi Keuangan PT Jaya Kontruksi Manggala Pratama Tbk \\ ${ }^{3}$ Sistem Informasi, STMIK Pranata Indonesia, Jln. Cut Mutia Raya No.28, Margahayu, Bekasi \\ E-mail: ${ }^{1} z y a d r @ f t i . u n t a r . a c . i d,{ }^{2}$ ria_a2b@yahoo.co.id, ${ }^{3}$ pranindo.dwi@gmail.com
}

\begin{abstract}
Abstrak
Tujuan dari penulisan makalah ini adalah mengembangkan sistem informasi rekondisi yang merupakan bagian dari pemeliharaan alat-alat berat terkomputerisasi agar memberikan kemudahan untuk pengolahan data serta pencarian data dengan hasil laporan yang sesuai. Sistem Informasi ini dirancang untuk rekondisi alat berat membantu perusahaan dalam mengurangi downtime mesin yang digunakan, sehingga berguna untuk ketersediaan alat berat yang siap pakai. Pengembangan sistem informasi ini menghasilkan aplikasi desktop yang mempunyai menu utama berupa menu berkas, transaksi, laporan, bantuan. Data yang ada berupa data alat, data proyek, data subkon, serta data transaksi yang selanjutnya dari datadata yang ada tersebut akan menghasilkan laporan proses administrasi workshop, laporan kegiatan rekondisi alat mulai dari perhitungan downtime, laporan schedule, hingga laporan serah terima alat.
\end{abstract}

Kata kunci-Rekondisi, Alat Berat, Downtime

\begin{abstract}
The purpose of this paper is to develop a recondition information system that is part of the maintenance of computerized heavy equipment in order to provide convenience for data processing and search data with the results of appropriate reports This Information System is designed for heavy equipment reconditioning to assist companies in reducing machine downtime used, making it useful for availability of ready to use heavy equipment. Development of this information system produces desktop applications that have the main menu in the form of file menus, transactions, reports, and help. The existing data are equipment data, project data, subcontract data, and transaction data and then from the existing data will produce report of workshop administration process, report of recondition equipment start from calculation of downtime, schedule report, until handover equipment report.
\end{abstract}

Keywords - Recondition, Heavy Equipment, Downtime

\section{PENDAHULUAN}

Rekondisi termasuk dari proses pemeliharaan alat. Rekondisi alat yang dimaksud yaitu perbaikan yang dilakukan secara tidak terjadwal tetapi sesuai dari status alat besar tersebut. Alat besar merupakan salah satu dari kategori alat berat berdasarkan ukuran. Alat besar merupakan alat yang memiliki ukuran besar dengan kapasitas lebih dari 60 Ton dan proses pemindahannya perlu menggunakan alat bantu lainnya [1]. Proyek merupakan usaha yang bersifat sementara 
untuk menghasilkan produk atau layanan yang unik. Subkon kepanjangan dari sub kontraktor sebagai pemborong dari kontraktor yang memiliki tender dalam waktu dan biaya yang ditentukan. Unit Pembelian dan Penjualan (UPP ) yang mengartikan posisi untuk mengatur proses pembelian, penjualan, penentuan harga-harga dalam operasional perusahaan.

PT. Jaya Konstruksi Manggala Pratama, adalah salah satu perusahaan konstruksi di Indonesia Perusahaan ini bergerak di bidang trading, construction, manufacturing, dan infrastructure. Rekondisi alat besar pada PT. Jaya Konstruksi Manggala Pratama terbilang kurang efisien dan lengkap dalam memberikan informasi hasil dari rekondisi alat besar baik berupa laporan maupun pencarian data. Setiap alat besar yang direkondisi tidak memiliki history untuk penilaian performance alat. Dari permasalahan rekondisi alat besar yang ada, mengakibatkan pada kinerja kepala workshop dalam pekerjaannya di sistem menjadi kurang sistematis, dan memperlambat pencarian data rekondisi yang dibutuhkan dengan cepat dan lengkap. Sehingga laporan yang diterima menjadi lambat secara keseluruhan.

Proses dan tata cara pelaporan rekondisi alat alat berat di PT. Jaya Konstruksi Manggala Pratama memang sudah ada, namun semua kegiatan masih secara manual, sistem belum terkomputerisasi. Penerapan teknologi informasi sebatas pencatatan data-data dengan Microsoft Office, perhitungan juga dilakukan secara manual dengan Microsoft Excel. Karena masih dilakukan secara manual maka tingkat terjadinya kesalahan menjadi tinggi serta akan memakan waktu yang lebih lama untuk mendapatkan hasil yang optimal yaitu informsi dalam bentuk laporan.

Dilihat dari masalah yang terjadi saat ini maka dibutuhkan adanya program aplikasi rekondisi alat berat sebagai bagian dari sistem pemeliharaan alat. Program aplikasi ini dapat membantu mempercepat proses kegiatan rekondisi alat mulai dari perhitungan downtime, laporan schedule, hingga laporan serah terima alat.

\section{METODE PENELITIAN}

\subsection{Pengembangan Sistem Informasi}

Metode yang digunakan pengembangan sistem disini adalah metode System Development Life Cycle (SDLC) dengan pendekatan Baker Method, yaitu merupakan suatu pendekatan untuk menentukan rincian pekerjaan masing-masing dari siklus yang ada pada SDLC [2]. Tahap-tahap yang ada pada Metoda Baker adalah sebagai berikut :

1. Strategy mencakup dua komponen utama yaitu model proses dasar dan model aliran data yang dapat digunakan untuk mengkonfirmasi pemahaman tentang tujuan, proses, dan kebutuhan bisnis [2].

2. Analysis, pada tahap ini dilakukan untuk mendapatkan semua proses yang akan digunakan dalam proyek penngembangan sisitem, dimana pada tahap in terdiri dari dua komponen yaitu Informatiom Gathering dan Requirement Analysis [2].

3. Design, merupakan rancangan bentuk fisik dari sistem seperti pengkodean, tampilan masukan dan keluaran, serta spesifikasi tabel [2].

4. Build, yaitu tahap pembuatan program dan pengujian program, dimana pada tahap ini pengujian program dilakukan oleh programer [2].

5. User Documentation, merupakan kesepakan tentang sistem baik bentuk ataupun performacenya oleh pengguna dan pemangku jabatan didokumentasikan dari tahapan strategy sampai dengan tahapan analysis [2].

6. Transaction, sebagai suatu tahapan yang memastikan bahwa pengujian telah selasai dan diperbaiki, intalasi perangkat keras dan perangkat lunak sudah diinstall [2]. 
7. Production, merupakan tahap mulainya penerapan dari sistem yang dikembangkan, pada tahap ini staf teknologi informasi dan personil pendukung bertanggung jawab untuk menyediakan layanan bagi pengguna, dilainhal tahapan dimana perbaikan oleh programer bila ada [2].

\subsection{Pemeliharaan Mesin}

Konsep pemeliharaan mesin dibagi menjadi dua kategori yaitu preventive mantenance dan corrective maintenance [3], dimana pengertian dari jenis-jenis pemeliharaan tersebut adalah:

1. Preventive maintenance ialah kegiatan pemeliharaan dan perawatan yang dilakukan untuk mencegah timbulnya kerusakan-kerusakan yang tidak terduga dan menemukan kondisi atau keadaan yang dapat menyebabkan fasilitas produksi mengalami kerusakan pada waktu digunakan dalam proses produksi [3]. Semua fasilitas produksi yang diberikan preventive maintenance akan terjamin kelancarannya dan selalu diusahakan dalam kondisi atau keadaan yang siap dipergunakan untuk setiap operasi atau proses produksi pada setiap saat. Sehingga dapatlah dimungkinkan pembuatan suatu rencana dan jadwal pemeliharaan dan perawatan yang sangat cermat dan rencana produksi yang lebih tepat.

2. Corrective maintenance adalah perawatan yang dilakukan untuk mengembalikan kondisi mesin ke kondisi standard melalui pekerjaan perbaikan atau penyetelan [3]. Berbeda dengan preventive maintenance yang pelaksanaannya teratur tanpa menunggu adanya kerusakan, corrective maintenance justru dilakukan setelah komponen telah menunjukkan adanya gejala kerusakan atau rusak sama sekali. Corrective maintenance terbagi menjadi macam, yaitu :

a. Repair and Adjusment adalah perawatan yang sifatnya memperbaiki kerusakan yang belum parah atau machine belum tidak bisa digunakan [3]. Misal, jika terjadi gangguan pada sistem pengisian (no charging), maka salah satu cara memperbaikinya adalah dengan melakukan penyetelan.

b. Breakedown Maintenance adalah perawatan yang dilaksanakan setelah tidak bisa digunakan. Hal ini biasanya terjadi karena adanya kerusakan yang diabaikan terus menerus tanpa ada usaha untuk memperbaikinya [3]. Kerusakan tersebut semakin lama semakin parah. Umumnya kerusakan kecil tadi menjadi besar dan menyebabkan komponen lain ikut menjadi rusak. Perawatan yang demikian ini akan menyebabkan biaya perbaikan melambung tinggi.

\subsection{Konsep Downtime}

Downtime adalah lamanya waktu dimana suatu unit/mesin tidak dapat menjalankan fungsinya sesuai dengan yang diharapkan, yaitu pada saat unit/mesin mengalami kerusakan [4]. Downtime terdiri dari beberapa unsur yaitu:

a. Supply delay, yaitu waktu yang dibutuhkan oleh personel maintenance untuk memperoleh komponen yang dibutuhkan untuk menyelesaikan proses perbaikan [3].

b. Maintenance delay, yaitu waktu yang dibutuhkan untuk menunggu ketersediaan sumber daya maintenance untuk melakukan proses perbaikan [3].

c. Acces time, yaitu waktu yang dibutuhkan untuk mendapatkan akses kekomponen yang mengalami kerusakan [3].

d. Diagnosis time, yaitu waktu yang dibutuhkan untuk menentukan penyebab kerusakan dan langkah perbaikan apa yang harus ditempuh untuk memperbaiki kerusakan [3].

e. Repair or replacement, yaitu waktu aktual yang dibutuhkan untuk menyelesaikan proses pemulihan setelah permasalahan dapat diidentifikasi dan akses ke komponen yang rusak dapat dicapai [3].

f. Verification and alignment time, yaitu waktu yang dibutuhkan untuk memastikan bahwa unit telah kembali pada kondisi operasi semula [3]. 


\subsection{Penggantian Berdasarkan Minimasi Downtime}

Penggantian berdasarkan kriteria downtime dilakukan dengan tujuan untuk menentukan waktu terbaik dilakukan penggantian guna meminimalkan total downtime per satuan waktu [5]. Terdapat dua macam model penentuan penggantian pencegahan optimal berdasarkan kriteria minimasi downtime ini [5], yaitu :

a. Model Block Replacement, penerapan model ini adalah dengan melakukan penggantian kerusakan yang terjadi dalam interval dengan mengabaikan adanya penggantian yang terjadi selama selang interval waktu tersebut, serta melakukan penggantian pencegahan pada setiap selang waktu secara konstan. Model memungkinkan terjadinya penggantian dalam kurun waktu yang berdekatan. Rumus perhitungan downtime untuk block replacement adalah sebagai berikut [4] :

$$
\mathrm{D}(\mathrm{tp})=\frac{\left(H\left(t_{p}\right) T_{f}\right)+T_{p}}{t_{p}+T_{p}}
$$

dimana,

$$
\begin{aligned}
& H\left(t_{p}\right)=\text { ekspektasi jumlah kegagalan dalam interval }(0, \text { tp }) \\
& \mathrm{t}_{\mathrm{p}} \quad=\text { interval waktu antara tindakan pemeliharaan preventive } \\
& \mathrm{T}_{\mathrm{f}} \quad=\text { waktu untuk melakukan perbaikan kerusakan komponen } \\
& \mathrm{T}_{\mathrm{p}} \quad=\text { waktu untuk melakukan penggantian preventive } \\
& \mathrm{D}(\mathrm{tp})=\text { Total Downtime block relpacement saat tp }
\end{aligned}
$$

b. Model Age Replacemen, model ini, pelaksanaan penggantian tergantung pada umur pakai dari suatu komponen. Penggantian dilakukan dengan menetapkan kembali interval waktu penggantian berikutnya sesuai dengan interval yang telah ditentukan jika dilakukan penggantian kerusakan. Rumus perhitungan downtime untuk model Age Replacement adalah sebagai berikut [5] :

$$
\mathrm{D}\left(\mathrm{t}_{\mathrm{p}}\right)=\frac{T_{p} \cdot R\left(t_{p}\right)+T_{f} F\left(t_{p}\right)}{\left(t_{p}+T_{p}\right) \cdot R\left(t_{p}\right)+\left(M\left(t_{p}\right)+T_{f}\right) \cdot F\left(t_{p}\right)}
$$

dimana,

$\mathrm{T}_{\mathrm{f}} \quad=$ waktu untuk melakukan perbaikan kerusakan komponen.

$\mathrm{T}_{\mathrm{p}} \quad=$ waktu untuk melakukan penggantian pencegahan

$\mathrm{t}_{\mathrm{p}} \quad=$ panjang interval waktu antara tindakan perawatan pencegahan

$\mathrm{M}\left(\mathrm{t}_{\mathrm{p}}\right)=$ nilai terngah distribusi kerusakan

$\mathrm{F}\left(\mathrm{t}_{\mathrm{p}}\right)=$ fungsi kepadatan peluang dari waktu kegagalan komponen.

$R\left(t_{p}\right)=$ Besarnya Probabilitas kerusakan pada waktu tp

$\mathrm{D}(\mathrm{tp})=$ Total Downtime age relpacement saat tp

\section{RANCANGAN DAN PEMBAHASAN}

\subsection{Permodelan Sistem}

Rancangan sistem informasi rekondisi alat berat pada PT. Jaya Konstruksi Manggala Pratama ini dapat digunakan untuk semua alat berat pada PT ini. Pada saat ini data alat berat yang digunakan untuk perancangan program aplikasi ini adalah alat berat yang telah digunakan untuk mengerjakan proyek yang ada. 


\subsubsection{Rancangan Modul}

Rancangan Modul pada progrm aplikasi ini terdiri dari beberapa modul yaitu :

1. Modul Berkas, merupkan modul untuk penginputan data terdiri dari tiga Sub modul yaitu Sub modul data alat yang digunakan pengguna untuk menginput alat alat berat yang ada di perusahaan, Sub modul Data Proyek untuk memasukan data proyek-proyek yang terkait dengan alat-alat berat yang diperlukan di dalam proyek-proyek tersebut, Sub modul Subkon (sub kontrkator) atau pemborong yang sedang mengerjakan proyek-proyek yang ada di perusahaaan.

2. Modul Transaksi, terdiri dari tiga sub modul yaitu Sub Modul Maintenance Downtime Schedule (MDTS) yang digunakan untuk menghitung jam kerja alat berat, hasil performace alat berat serta downtime dari alat berat. Sub modul Schedule merupakan modul untuk penentuan dari penjadwalan perbaikan alat berat setelah digunakan. Sub modul berita acara yaitu sub modul untuk berita acara dari penerimaan alat yang akan diperbaiki pada bengkel atau workshop.

3. Modul Laporan, merupakan modul untuk menampilkan laporan yang ada terdiri dari empat sub modul yaitu Sub modul laporan Alat berat yang Rusak, Sub modul laporan alat berat yang tidak rusak, Sub Modul laporan Alat berat yang sedang Rekondisi dan Sub Modul Laporan alat berat selesai direkondisi.

4. Modul Batuan digunakan sebagai modul batuan dalam menjalankan program

5. Modul Keluar Program, merupakan modul yang digunakan sebagai keluar dari program.

\subsubsection{Permodelan Data dan Simulasi Perhitungan}

Permodelan data disini dapat dilihat melalui diagram diagram sebagai berikut yaitu digram aliran data, dan diagram hubungan antar entitas serta alur simmulasi perhitungan.

Diagram konteks yang ada pada PT Jaya Kontruksi Manggala Pratama dapat dilihat pada Gambar 1, yang terdiri dari 4 entitas luar yaitu Ka. Pool (kepala pool) sebagai penanggung jawab perbaikan alat, UPP (Unit Pembelian dan Penjualan) sebagai yang mengatur proses pembelian, penjualan, penentuan harga-harga dalam operasional perusahaan, Proyek yaitu bertanggung jawab terhadap usaha yang bersifat sementara untuk menghasilkan produk atau layanan yang unik serta Subkon (Sub Kontraktor) pemborong dari kontraktor yang memiliki tender dalam waktu dan biaya yang ditentukan

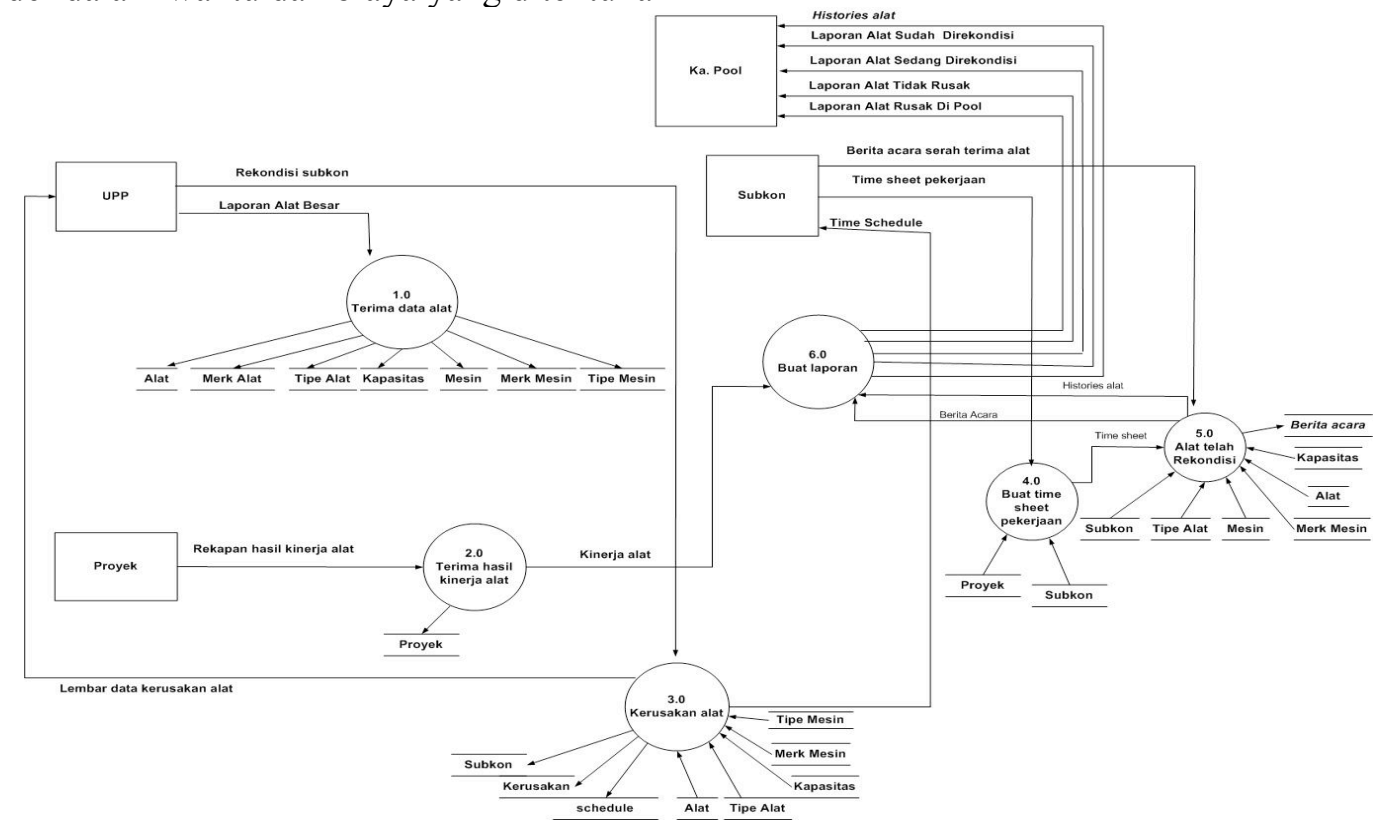

Gambar 1. Diagram Aliran Data Level 0 
Diagram hubungan antar terdapat dimana ada 12 entitas yang saling berhubungan, untuk lebik jelasnya dapat dilihat pada gambar 2

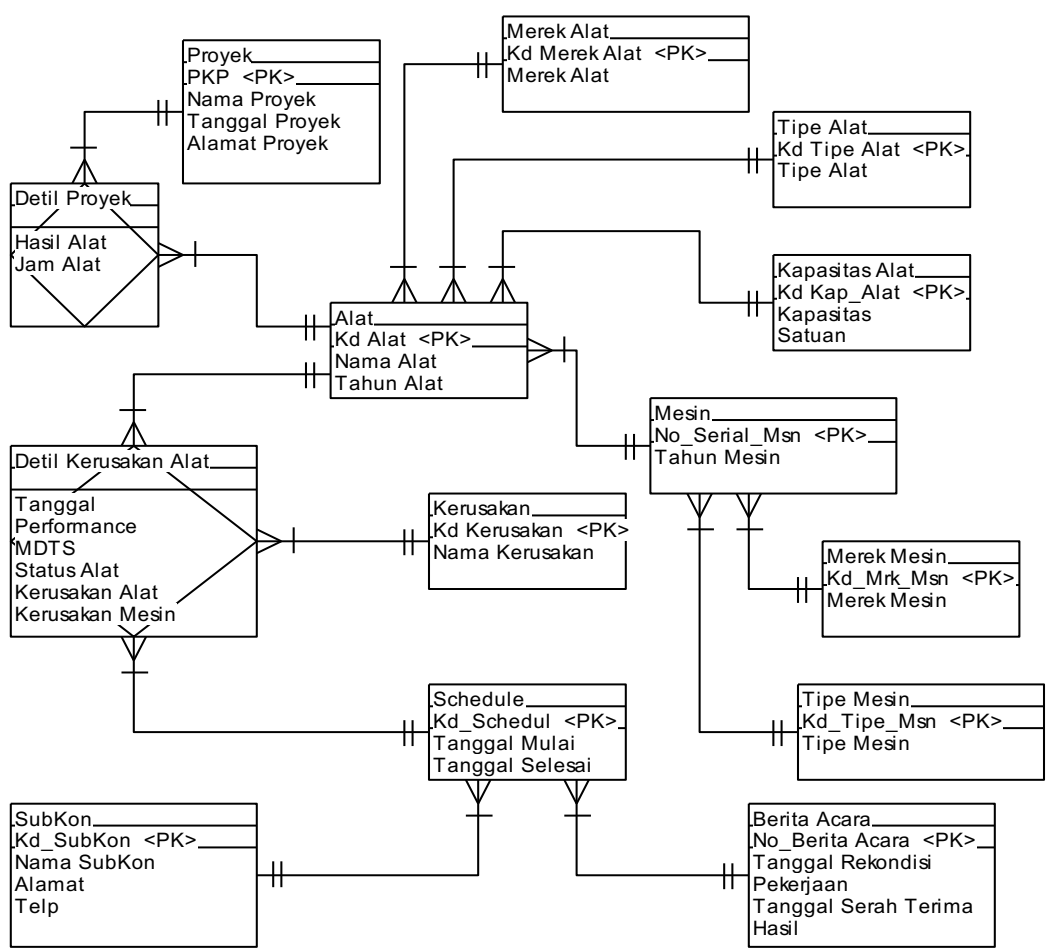

Gambar 2. Diagram Hubungan Antar Entitas.

Alur simulasi perhitungan program aplikasi rekondisi alat berat dimulai dengan menentukan Jenis Alat Besar yang sedang di rekondisikan berdasarkan kode Alat Besar, lalu dihitung hasil alat dan jam kerja alat, selanjutnya menghitung perfomance alat yang dilanjutkan terakhir adalah mengghitung downtime alat besar menggunakan rumus downtime yang tepilih pada saat menghitung Maintenance Downtime Schedule (MDTS). Sedangkan model penggantian pencegahan yang digunakan dalam program aplikasi ini adalah medel block replacement agar dapat minimasi downtime sehingga lebih murah dalam segi biaya administrasin yang harus dikeluarkan dan menghemat ongkos. Gambar alur simulasi perhitungan dapat dilihat pada Gambar 3.

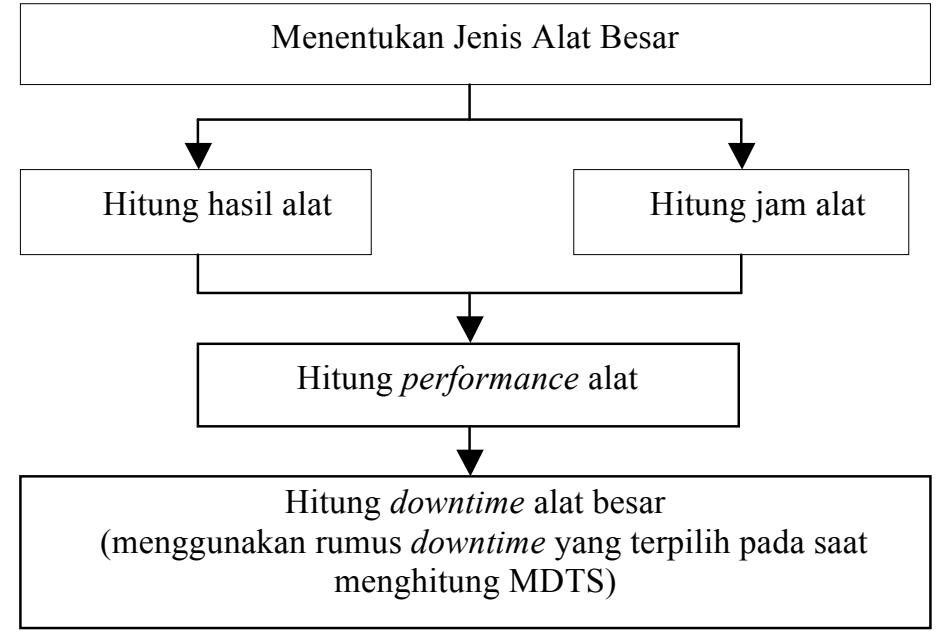

Gambar 3. Alur simulasi perhitungan 
Untuk menghitung performance alat dan MDTS yang ada, PT Jaya Kontruksi Manggala Pratama menggunakan rumus :

Performance $=\frac{\text { Total Aktual Output }}{\text { Aktual Standard } x \text { Total Jam Kerja }} \times 100 \%$

dimana,

Total Aktual Output $=$ Waktu yang digunakan Alat Berat selama pekerjaan per Proyek

Aktual Standard = Standar waktu per Alat Berat per proyek

Total Jam Kerja = Total waktu atau umur kerja dari Alat Berat

$$
\text { MDTS }=100 \%-\text { Performance }
$$

\subsection{Rancangan Masukan dan Keluaran}

Terdapat 18 masukan dalam bentuk form dan 6 Keluaran dalam bentuk report, beberpa form dan report dapat dilihat pada gambar berilut ini
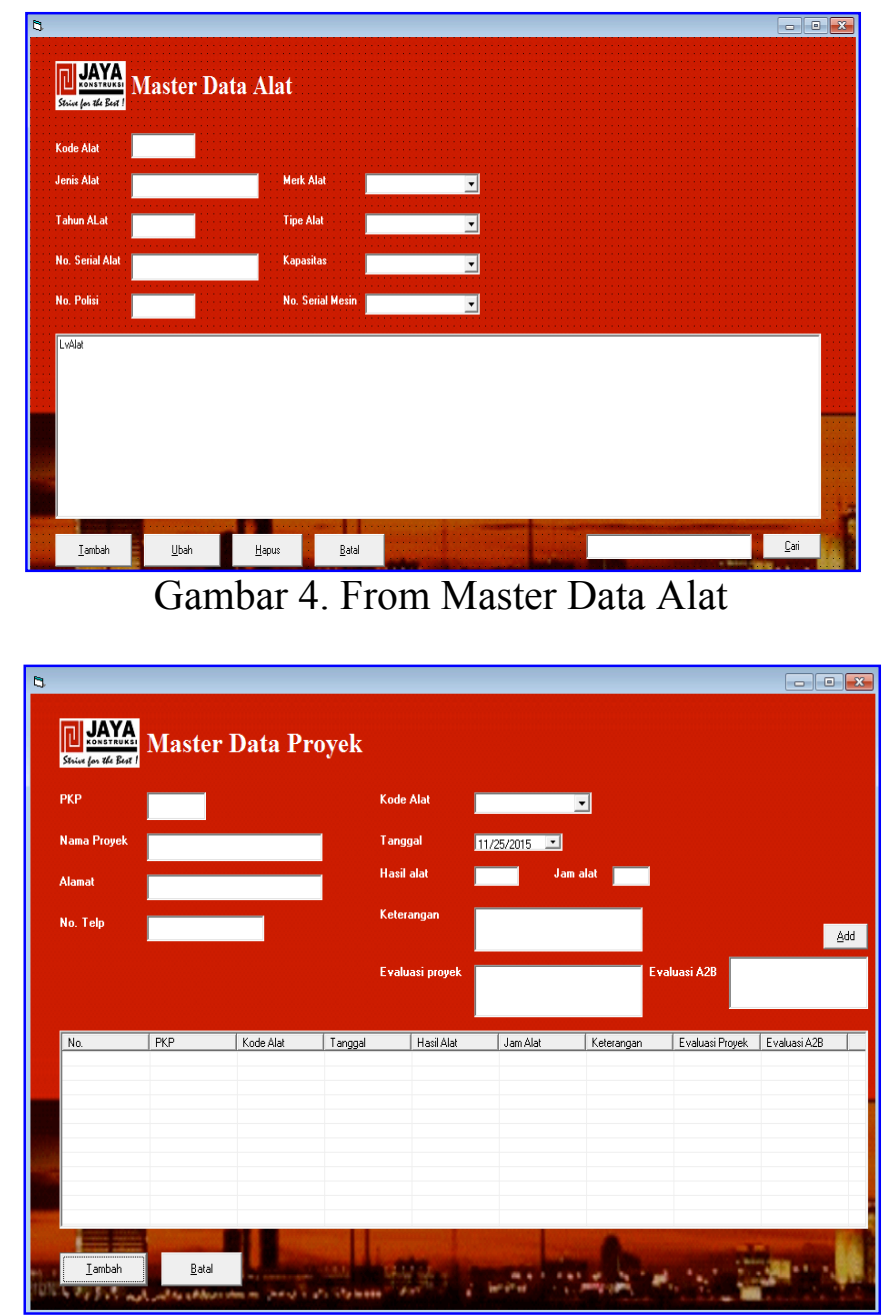

Gambar 5. Form Master Data Proyek 
Computatio: Journal of Computer Science and Information Systems, volume 1, no 2, Oktober 2017

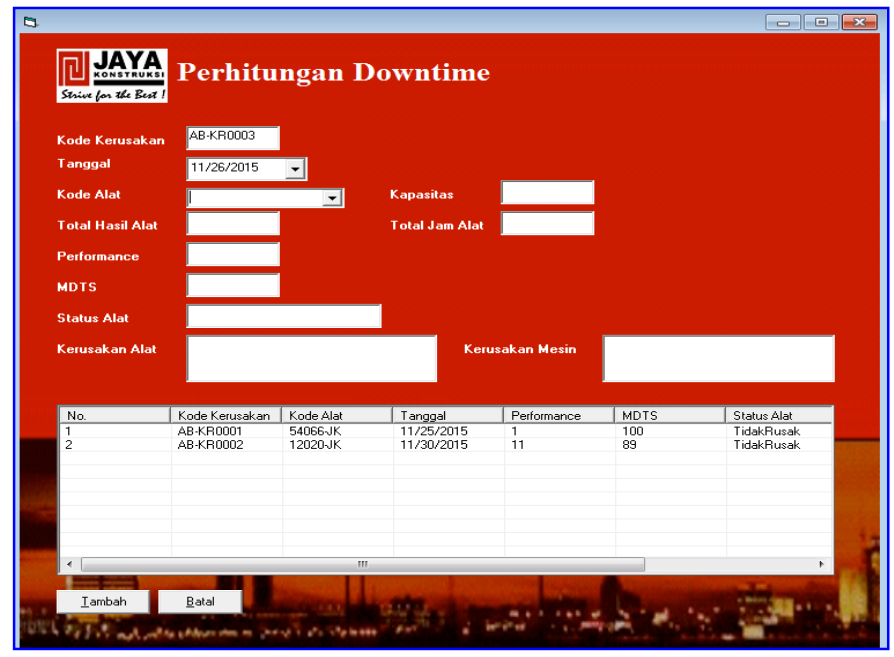

Gambar 6. Form Pehitungan Downtime

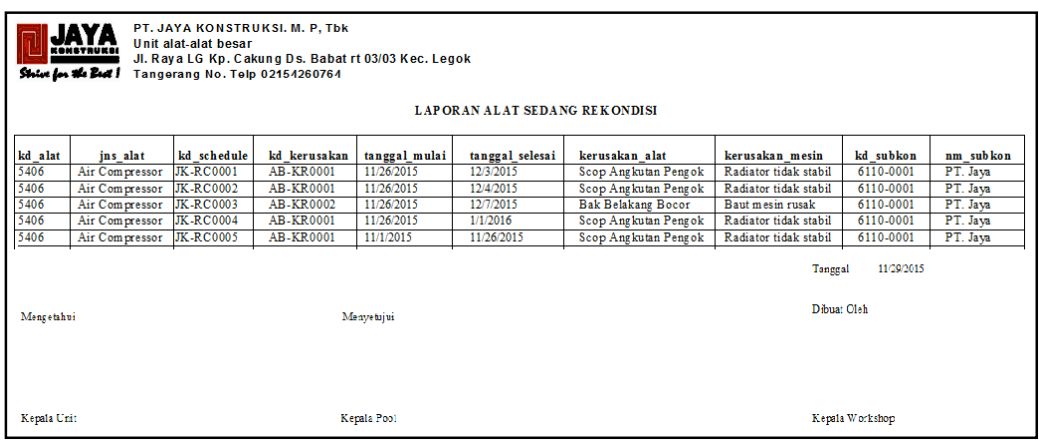

Gambar 7. Report Alat sedang Rekondisi

\subsection{Hasil Pengujian}

Pengujian dilakukan pada program aplikasi rekondisi alat berat ini untuk mengetahui apakah form-form yang ada sudah berfungsi dengan baik atau tidak. Pengujian dilakukan dengan menjalankan program lalu memasukkan input data dan menghasilkan keluaran yang diharapkan dari fungsi program tersebut. Berdasarkan hasil pengujian yang telah dilakukan semua form-form sudah berjalan dengan baik.

Sedangkan berdasarkan hasil percobaan program aplikasi ini menghasilkan output yang hampir sama antara penghitungan secara manual dan penghitungan menggunakan program aplikasi. Selisih perhitungannya terletak pada berapa angka dibelakang koma.

\section{KESIMPULAN}

1. Rancangan Sistem Informasi yang terkomputerisasi ini dapat memberikan solusi untuk rekondisi alat dengan meminimalisasi downtime berdasarkan waktu penggantian dan pemeriksaan alat yang optimal untuk setiap Alat Berat.

2. Rancangan sistem informasi yang terkomputerisasi ini dapat memberikan peringatan untuk rekondisi Alat Berat beserta spare part mesinnya, serta dapat sebagai pembuat laporan untuk penggunaan spare part setiap proyek yang dikerjakan. 


\section{DAFTAR PUSTAKA}

[1] Rostiyanti Susy Fatena. 2008. "Alat Berat Untuk Proyek Konstruksi”, PT. Rineka Cipta, Jakarta .

[2] Langger Arthur M 2008, "Analisys and Design of Information System" Third Edition, ISBN 978-1-84628-654-4, e-ISBN 978-1-84628-655-1, Springer-Verlag London

[3] Dhillon B.S. 2002, "Engineering Maintenance: a Modern Approach", ISBN 1-58716142-7, CRC Press, LLC, Washington D.C.

[4] Ebeling, Charles E. 2005, "An Introducton to Realibility and Maintainability Engineering", The Mc Graww-Hill Companies, Singapore Inc,

[5] Jardine AKS, Tsang AHC. 2013, "Maintenance, Replaceemnt and Reliability Theory And Applicationals ”, ISBN 978-1-4665-5486-3, CRC Taylor Fancis Group, LLC, New York. 